\title{
Determining the Environmental and Economic Benefits of Life Cycle Assessment on Example of the Power Plants in Poland
}

\author{
Maciej Dzikuć \\ University of Zielona Góra, Zielona Góra, Poland \\ Maria Dzikuć \\ Wrocław University of Economics, Wroclaw, Poland
}

\begin{abstract}
The paper presents a method of life cycle assessment (LCA) to determine the impact of the electricity produced on the environment. To determine the environmental burdens and benefits the LCA technique is used, methodologically based on ISO 14040 series. In addition, the usefulness of this method to assess the energy sector has been shown. To evaluate the process, SimaPro software and the method of Eco Indicator 99 were used, which allows to get the results of the burden and benefit with taking into account three categories of damages: ecosystem quality, human health, and raw materials. This paper presents the impact of electricity generation on the environment in coal power plants. The article also points to the directions of the Polish energy sector and pointed to the need to determine the environmental risks associated with the production of energy. A detailed analysis by the method of LCA is made to compare the environmental impact of electricity generation in the Lagisza Power Plant and Turów Power Plant. It is pointed to the difference in the results obtained. Moreover, the causes of the reported environmental impacts are discussed. Measures are identified which will help to reduce in the future the impact of the electricity produced on the environment during the production of electricity.
\end{abstract}

Keywords: energy sector, ecology, economy, environmental impact, coal

\section{Introduction}

From the point of view of generating energy management practices is necessary to estimate the amount of required energetic resources, materials, the amount of emitted dust, solid wastes (ashes), which is generated in the course of production as well as electricity, which is also necessary during energy production. It is also crucial to consider the distance and means of transport of energetic resources from the place of extraction to the power station (Dzikuć, 2013b). In recent years, there has been a substantial increase of requirements concerning the very manner of energy production and its impact on the environment. There appeared a need for finding such a tool, which would take into consideration many aspects of the issue. The main objective of this paper is to present the life cycle assessment (LCA) method, which is an effective tool helping provide a complex

Maciej Dzikuć, Ph.D., Eng., Faculty of Economics and Management, University of Zielona Góra.

Maria Dzikuć, Ph.D. candidate, Faculty of Engineering and Economics, Wrocław University of Economics.

Correspondence concerning this article should be addressed to Maciej Dzikuć, University of Zielona Góra, Faculty of Economics and Management, 65-001 Zielona Góra, ul. Podgórna 50, Poland. E-mail: M.Dzikuc@wez.uz.zgora.pl. 
evaluation of particular manners of energy production (Dzikuć \& Piwowar, 2013).

The last couple of years have brought some important changes in the electric power industry that can be observed in most EU countries. Energy strategy of the EU has become one of the most important factors influencing the development of the member states. Poland is a country with electric energy produced predominantly in hard and brown coal-fired power stations (Urban \& Dzikuć, 2013).

All coal-fired power stations affect the environment in a negative way. As a result of the rising levels of environmental pollution, ways of limiting the negative human impact on the environment are being sought. Novel solutions, aimed at reducing the negative impact on the environment, are being introduced as a reaction to the rising awareness of the society and increasingly more stringent requirements imposed by laws. One of the ways allowing an evaluation and comparison of the environmental impact of different means of energy generation is the LCA method. The LCA can be applied to products, processes (encompassing full life cycle) as well as to entire branches of industry (Dzikuć, 2013a). In connection with the growing importance of energy efficiency in industry, the paper provides examples of the LCA applications to two electric power plants: the Łagisza Power Plant and Turów Power Plant.

The Polish economy is heavily dependent on coal, and is particularly sensitive to the EU's determination to protect the environment. The EU is a political region with serious approach about the commitments related to the elimination of environmental hazards, particularly for: climate change, biodiversity, and air quality (Björklund, 2012). The use of LCA in this sector is a good solution, since this technique allows to identify specific environmental influences (among others: climate change, biodiversity, and air quality), to determine their size, which allows for the accurate assessment, comparison, process optimization, or elimination (Zarębska \& Dzikuć, 2013).

\section{Research Method}

Ecological LCA is a research method aimed at an analysis of environmental problems. Such an analysis is based on identifying and determining the amount of used up materials and energy, as well as on determining the pollution levels, and on a subsequent evaluation of the impact these elements might have on the environment (Dylewski \& Adamczyk, 2012). This method can be used to identify potential problems and help to determine ways of improving environmental quality.

One of the main goals of the LCA method is to analyse the potential impact of production processes on the environment and to determine ways to improve the quality (Łasiński, 2012) of the environment. The possibility of the "cradle-to-grave" product analysis is an important feature of the LCA method. It is also possible to determine the environmental impact of a product not only during the production or resources acquisition phases but also during the product usage and utilisation phases (Dylewski \& Adamczyk, 2011). The LCA method allows an effective management of limited resources, since it is based on real input and output data of a given process (Zhang \& Colosi, 2013).

LCA is an established method for assessing the potential environmental impact associated with a product or service system (Wach, 2002). A LCA consists of four main phases:

(1) Goal and scope definition describes the objective of the study (goal), and the methodological approach used (scope);

(2) Inventory analysis examines the processes in the product system and quantifies for each process all the input and output data (i.e., inventory data). Economic inventory data include the amount of resources, materials, 
and energy needed to manufacture a product. Environmental inventory data include all extracted natural resources which are used in the process (inputs), and emissions and waste released to the environment (outputs);

(3) Impact assessment converts the inventory data into their contribution to environmental impact in one or more impact categories, e.g., global warming potential, resource depletion, eutrophication, toxicity;

(4) Interpretation evaluates the results and their robustness from the previous phases and draws conclusions and/or recommendations. This phase also examines the confidence and reliability of the LCA results through sensitivity, scenario, and/or uncertainty analyses (Harst \& Potting, 2103).

The International Standard Organization (ISO) defines the LCA as a method allowing an analysis of environmental aspects and of a potential production impact. To the implementation of the LCA a computer program SimaPro and the procedure Eco Indicator 99 were used.

This procedure allows the unequivocal assignment of the 11 categories to three categories of impact damage, such as human health (Human Health), the quality of the ecosystem (Ecosystem Quality), and natural resources (Resources). Additionally, it enables to present the final results of LCA in the dimensionless unit referred to as the so-called eco-point (Pt) (Eco-indicator 99). Value $1 \mathrm{Pt}$ reflects the ratio of the total annual burden on the environment in Europe (emissions, the volume of consumption of raw materials) to the number of its inhabitants, and multiplying by 1,000 (scale factor). In this way the Eco Indicator 99 of 1,000 Pt corresponds to an annual total environmental load per capita in Europe (Zarębska \& Dzikuć, 2013).

The analysis following the above steps renders is possible to picture the impact and divide it into 11 main categories: carcinogenic compounds, organic compounds, inorganic compounds, climate change, radiation, ozone hole, ecotoxicity, acidification/euthropication, land use, fossil fuels and three damage categories: human health, ecosystem quality, resources consumption including the type (Dzikuć, 2013b), normalisation and a final score (weighting) that measures the environmental impact of a product in $\mathrm{Pt}$ (eco indicator point) units, where 1 ecopoint $(\mathrm{Pt})$ expresses a value representing one thousandth of a yearly environmental impact of one inhabitant of Europe (Dąbrowski \& Dzikuć, 2012). The use of methods such as the LCA can save the amount of energy resources consumed. Lower resource consumption helps to ensure energy security. LCA method is especially useful for analysis to determine the impact on the environment during the production of energy. In Poland, more than $90 \%$ of electricity is produced by burning coal and lignite. Consumption of non-renewable energy resources has a negative impact on the environment. When it comes to the energy of emission of toxic gases into the atmosphere. Through an analysis of LCA is possible to evaluate and compare the various energy technologies and exhaust after-treatment. LCA method takes into account the amount of energy consumed, which also is of great importance when comparing the impacts on the environment, which takes place during the production of electricity (Dzikuć, 2013c).

Interpretation is a phase of LCA, whose task is to analyze conclusions, check completeness, analyze sensitivity, other analyses, recommendations and report. Moreover, this phase allows to define elements of great risk, analysis of sensitivity of above mentioned elements, to define the manner of minimization of threats as well as assess priorities of possible corrections and their feasibility (Radhi \& Sharples, 2013). The impact assessment allows for defining trustworthiness of results at a high level and formulated conclusions and elaborated recommendations become a complete and objective report from the research. The assessment conducted according to the mentioned procedure allows to present the results of impact in relation to nine impact categories included in Table 1. The presentation of the result of environmental interference of electricity, 
as well as other products subject to the assessment, takes place in the form of Pt units (point of eco indicator), where 1 point of eco indicator $(\mathrm{Pt})$ is a value, which represents one thousandth of annual environment load of one citizen in Europe (Piwowar \& Dzikuć, 2013).

Table 1

Categories of Environmental Impact

\begin{tabular}{|l|l|l|}
\hline No. & Category & Description \\
\hline 1 & Abiotic impoverishment & Extraction of non-renewable ores of mineral resources \\
\hline 2 & Energy impoverishment & Extraction of non-renewable energy carriers. This category can be included in category 1 \\
\hline 3 & Greenhouse effect & Atmospheric absorption of radiation leading to the increase of global temperature \\
\hline 4 & Ozone hole & $\begin{array}{l}\text { Increase of ultraviolet radiation reaching the surface of Earth caused by impoverishment } \\
\text { of ozone layer }\end{array}$ \\
\hline 5 & Water and soil contamination & Exposing biota to toxic substances \\
\hline 6 & Acidification & Increase of water and soil acidity \\
\hline 7 & Contamination of humans & $\begin{array}{l}\text { Exposing human health to toxic substances appearing in water, air, and soil, mainly with } \\
\text { food }\end{array}$ \\
\hline 8 & Creating photochemical oxidants & Emergence of atmospheric particles causing photochemical smog \\
\hline 9 & Eutrophication & $\begin{array}{l}\text { Reduction of oxygen amount in water or soil by emission of substances causing increase } \\
\text { of biomass production }\end{array}$ \\
\hline
\end{tabular}

Note. Source: Clift, 1997.

\section{Results and Analyses}

The Łagisza Power Plant is located in Będzin in Zagłębie Dabrowskie. Primary activity of the Lagisza Power Plant is the production transmission and sale of electricity. The Power Plant Lagisza is a professional power plant with $840 \mathrm{MW}$ of electric power. The Lagisza Power Plant is located in the neighborhood of coal mines in the industrialized region. Near the the Łagisza Power Plant there is also a large number of potential consumers of electricity. The Power Plant Łagisza operates on the coal.

The Turów Power Plant is a thermal power plant, a condensation block of intercooled reheat of steam and closed cooling water system. The share of power installed in the Turów Power Plant in the Polish energy system is about $7 \%$. The main fuel in the Turów Power Plant is brown coal.

The Łagisza Power Plant produced in 2012, 3,958,191 MWh, while the Turów Power Plant produced in 2012, 11,898,898 MWh. In 2012, the Łagisza Power Plant issued 3,546,545 $\mathrm{Mg}$ of $\mathrm{CO}_{2}$. However, the Turów Power Plant issued $10,802,510 \mathrm{Mg}$ of $\mathrm{CO}_{2}$ in the same year.

The objective is to determine and compare the environmental impact of thermal energy based on coal using the LCA, a computer program SimaPro. $1 \mathrm{MWh}$ is used as a functional reference unit of the system which describes the impact of the product on the environment (e.g.:1 ton of coal).

The data that were used to study come from 2012 and include the elements included in the system used in the production of electricity, such as coal, water, electricity and outgoing parts of the production system, the amount of produced electricity and heat, and any resulting contamination during production.

The results of the LCA applied to the three damage categories (see Table 2 and Figure 1) show that the category "resources" has the highest environmental impact, with energy production from coal. However, studies show that larger impact on the environment was characterized by the production of electricity in the Łagisza Power Plant (hard coal-fired). This can be explained by the fact that the hard coal reserves are scarce. 
Table 2

The LCA Results-The Three Damage Categories

\begin{tabular}{llcc}
\hline Impact categories & Unit & Lagisza Power Plant & Turów Power Plant \\
\hline Human health & $\mathrm{Pt}$ & 7.28 & 7.23 \\
Ecosystem quality & $\mathrm{Pt}$ & 0.90 & 0.30 \\
Resources & $\mathrm{Pt}$ & 19.57 & 17.74 \\
Total & $\mathrm{Pt}$ & 27.75 & 25.27 \\
\hline
\end{tabular}

Note. Source: Compiled on the basis of the result obtained with SimaPro.

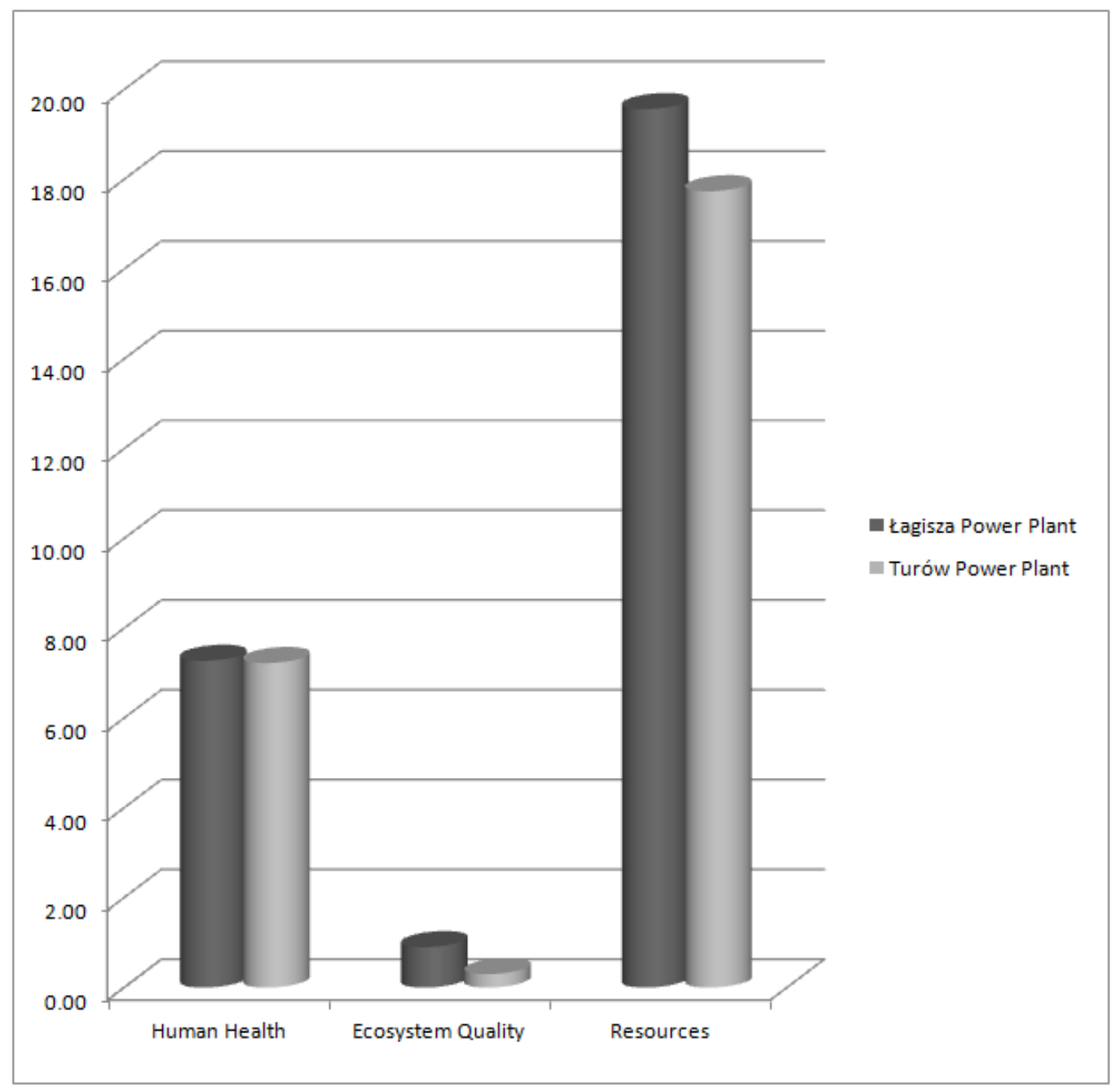

Figure 1. The LCA results - the three damage categories. Source: Compiled on the basis of the result obtained with SimaPro.

The next important factor affecting the environment in relation to the three damage categories is the "human health" category. The largest impact on "human health" has harmful emission into the atmosphere (see Table 3). Here the impact of energy production from hard coal and brown coal is several times smaller. Contrast these results in the category of "human health". The difference in this category is much smaller than in the case of the category "resources". The least impact of the final result the research was aimed at category "ecosystem quality". However, in this category were the biggest differences in the results. The Lagisza Power Plant was three times greater impact on the environment than the Turów Power Plant in this categories impact. 
Table 3

Emissions of Gaseous and Particulate (2012)

\begin{tabular}{lrr}
\hline Harmful emissions & Łagisza Power Plant & Turów Power Plant \\
\hline Particulates & $1,345 \mathrm{Mh}$ & $243 \mathrm{Mg}$ \\
$\mathrm{SO}_{2}$ & $33,627 \mathrm{Mg}$ & $3,818 \mathrm{Mg}$ \\
$\mathrm{NO}_{2}$ & $11,790 \mathrm{Mg}$ & $5,678 \mathrm{Mg}$ \\
$\mathrm{CO}_{2}$ & $11,109,188 \mathrm{Mg}$ & $3,546,545 \mathrm{Mg}$ \\
\hline
\end{tabular}

Note. Source: Retrieved from http://www.elturow.pgegiek.pl/ \& http://www.pke.pl/elektrownie.

All three categories of impact indicate a higher impact on the environment in the event of the Lagisza Power Plant. This is a clear impact. A less negative impact in the case of the Turów Power Plant results from the application of brown coal in it. Production of electricity using the brown coal allows significant savings of energy resources. It also renders it possible to achieve lower indicators of emissions per unit of energy produced.

Factor hindering the development of electricity generation by means other than through the burning of coal is the high cost of generating electricity using other raw materials or energy production based on renewable energy sources.

\section{Conclusions}

Electricity generation using more ecological methods currently has economic significance. Poland is a country that pays fees for $\mathrm{CO}_{2}$ emissions. In Poland, over $90 \%$ of electricity is produced by using coal. Use own energy resources is economically justified. However, it is necessary to find solutions that will limit harmful emissions into the atmosphere.

It should be noted that there is a significant difference between the environmental impacts of energy production in the Łagisza Power Plant and the Turów Power Plant. Poland as a country having large coal reserves will use this source of energy for decades. It is therefore important to develop energy technologies based on coal. As studies show it is possible to minimize the negative environmental impacts of energy production.

Generations of electricity in coal-fired power plants have a negative impact on the environment. Looking for solutions that will help reduce the environmental impact related to energy production is of great significance for people and ecosystem quality. The difference in the analyzed results shows that it is possible to effectively reduce the negative impact on the environment. The Turów Power Plant by generating electricity is able to provide less environmental impact per unit of electricity generated. Calculated environmental burdens indicate that technologies using brown coal in this case have a smaller impact on the environment.

\section{References}

Björklund, A. (2012). Life cycle assessment as an analytical tool in strategic environmental assessment: Lessons learned from a case study on municipal energy planning in Sweden. Environmental Impact Assessment Review, 32, 82-87.

Clift, R. (1997). Life cycle assessment (p. 294). Guildford: University of Surrey.

Dąbrowski, R., \& Dzikuć, M. (2012). Life Cycle Assessment (LCA) in energy sector (Ocena cyklu życia w sektorze energetycznym). The Measurements, Automation and Monitoring (Pomiary, Automatyka, Kontrola), 58(9), 819-821.

Dylewski, R., \& Adamczyk, J. (2011). Economic and environmental benefits of thermal insulation of building external walls. Building and Environment, 46(12), 2615-2623.

Dylewski, R., \& Adamczyk, J. (2012). Economic and ecological indicators for thermal insulating building investments. Energy 
and Buildings, 54, 88-95.

Dzikuć, M. (2013a). Applying the life cycle assessment method to an analysis of the environmental impact of heat generation. International Journal of Applied Mechanics and Engineering, 18(4), 1275-1281.

Dzikuć, M. (2013b). The application of life cycle assessment (LCA) to assess the impact of electricity generation on the environment (Zastosowanie analizy cyklu życia (LCA) do oceny wpływu wytwarzania energii elektrycznej na środowisko). Electrical Review (Przeglad Elektrotechniczny), 4, 33-36.

Dzikuć, M. (2013c). Energy security of urban and rural lubuskie land (Bezpieczeństwo energetyczne miast i wsi województwa lubuskiego). Energy Market (Rynek Energii), 1(104), 56-61.

Dzikuć, M., \& Piwowar, A. (2013). LCA analysis as a tool to assess the impact of electricity production on the environment. Management, 17(1), 382-392.

Harst, E., \& Potting, J. (2013). A critical comparison of ten disposable cup LCAs. Environmental Impact Assessment Review, 43, 86-96.

Łasiński, K. (2012). Modern methods of quality control measurements by means of CCD cameras-A model selection. International Journal of Applied Mechanics and Engineering, 17(3), 899-906.

Piwowar, A., \& Dzikuć, M. (2013). Characteristics of agricultural biogas manufacturers in Poland (Charakterystyka podmiotów zajmujących się wytwarzaniem biogazu rolniczego w Polsce). Journal of Agribusiness and Rural Development, 1(27), 207-217.

PN-EN ISO 14044. (2009). Environmental management: Life cycle assessment: Requirements and guidelines (Zarzadzanie środowiskowe: Ocena cyklu życia: Wymagania i wytyczne) (pp. 47-53). Warsaw: Polish Committee for Standardization (Polski Komitet Normalizacyjny).

Radhi, H., \& Sharples, S. (2013). Global warming implications of facade parameters: A life cycle assessment of residential buildings in Bahrain. Environmental Impact Assessment Review, 38, 99-108.

Urban, S., \& Dzikuć, M. (2013). The environmental impact of electricity production in coal-fired power plants (Wpływ na środowisko wytwarzania energii elektrycznej w elektrowniach opalanych węglem kamiennym). Economy and Environment (Ekonomia i Środowisko), 2, 84-92.

Wach, A. K. (2002). Method of Life Cycle Assessment (LCA) as a basis for computer-assisted assessment of the product (Metoda oceny cyklu życia (LCA) jako podstawa komputerowo wspomaganej oceny wyrobu) (p. 92). Warsaw: The Industrial Institute of Electronics (Przemysłowy Instytut Elektroniki).

Zarębska, J. (2013). Ecological and economic aspects of packaging waste management in Lubuskie (Ekologiczne i ekonomiczne aspekty gospodarki odpadami opakowaniowymi w województwie lubuskim) (pp. 106-110). Publishing House of the University of Zielona (Oficyna Wydawnicza Uniwersytetu Zielonogórskiego).

Zarębska, J., \& Dzikuć, M. (2013). Determining the environmental benefits of life cycle assessment (LCA) on example of the power industry. Scientific Journals Maritime University of Szczecin, 34(163), 97-102.

Zhang, Y., \& Colosi, L. M. (2013). Practical ambiguities during calculation of energy ratios and their impacts on life cycle assessment calculations. Energy Policy, 57, 630-633. 